\title{
Chapter 7. Traditional Territorial Categories and Constituent Institutions in West Seram: The Nili Ela of 'WELE Telu Batai and the Alune Hena of Ma'saman Uwei
}

\section{Christine Boulan-Smit}

\section{Introduction}

Seram, the largest island of the Moluccas, lies only a few hours by boat from the regional capital city of Ambon. According to tradition, Seram is referred to as Nusa Ina, the 'Mother Island'. An Alune narrative, collected by A.D.E. Jensen, recalls that at one time in the past Seram, Ambon and the Uliase Islands (Saparua, Haruku and Nusalaut) formed a single island where warfare was constant. So, the people of Ambon cut off a large parcel of land, tied it with human hair and dragged it to where it lies nowadays. Later, those of Saparua, Haruku and Nusalaut did the same and they have been separated from their Mother Island ever since. However, all know that once upon a time they were part of Seram and this is why they call Seram Nusa Ina and why the members of the same origin groups are spread out over all of these islands. ${ }^{1}$

Seram is now divided administratively into three regions: West, Central and East Seram. This paper focuses on Seram's western region, which is called 'Wele Telu', the 'Three Large Rivers', and encompasses roughly one-fifth of the island (about 35,000km2). It examines how West Seramese traditionally envisioned their land at the regional and domain level. The first part of the paper considers the categorical divisions of an ancient inter-domain institution, the Nili Ela (or Saniri Ela, 'Large Assembly') of 'Wele Telu Batai (The Three Large River Valleys), now mostly a feature of the past. This ancient league ${ }^{2}$ linked the highland domains of the 'Wele Telu area and their coastal allies or 'rulers'. These loose and changing networks of political and ritual alliances seem to have been in place as far back as the 14th century. The Nili institution was abolished by the Dutch Colonial Government in 1914, but still operated informally and in secret at least until the middle of the 20th century. ${ }^{3}$

The highland valleys of West Seram are settled by two linguistically related groups, the Wemale in the east and the Alune in the west. Their modern desa or villages usually correspond to former traditional territorial units or domains. The second part of the paper focuses on such a traditional Alune domain, or 
hena. The paper investigates how Hena Ma'saman Uwei (by metathesis, Manusa Manuwe), a semi-autonomous highland domain previously part of 'Wele Telu Batai, conceived of itself in the early 1990s and how particular categories or groups of people were allocated rights and responsibilities for specific divisions of its land.

\section{Map 1: West Seram, Ambon and Uliaser}

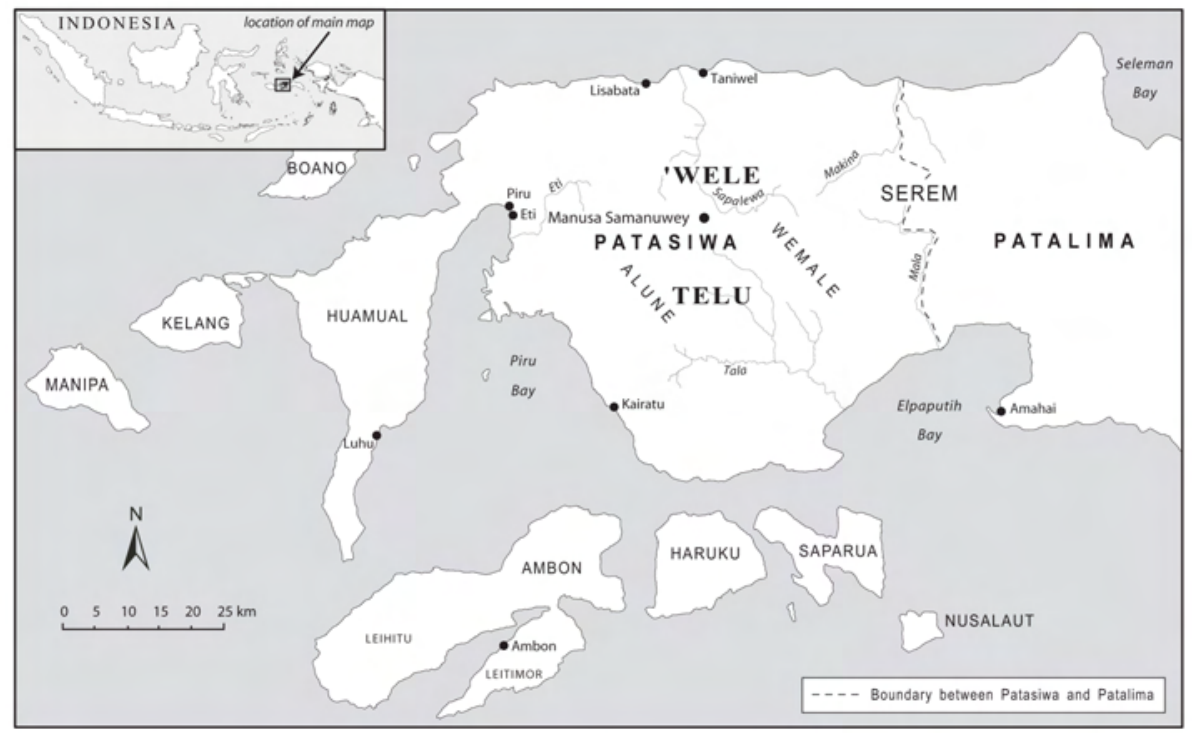

\section{The Setting}

Because of its reputation for inaccessibility, Seram was for centuries the refuge of sizeable communities of pirates, dissidents and separatists groups from neighbouring islands who brought in new knowledge and goods. ${ }^{4}$ Traders and migrants from Sulawesi and Java also settled along the coasts. In the second half of the 20th century, they were joined by sizeable communities of transmigrants and resettled families.

In the 1990s, the majority of the population was concentrated in the low hills and along the coast but a handful of villages still clung to their ancient highland traditional territories. 5 The trend to 'modernity' promoted an ideology of uniformity, but the mountain and coastal populations lived in different environments and had distinct modes of subsistence, social organisation and cultural values. Mountain groups were essentially forest farmers who hunted and gathered forest products to complement their diets or to trade at the coast. The diverse populations established along the coasts and in the low hills were involved in sedentary agriculture, fishing, trade, the plywood industry, or belonged to the sizeable military and administration posts established there. 
With the influx of migrants, the coastal population was, in majority, Muslim with interspersed Christian settlements. The highlanders, converted by the Dutch-Ambonese Protestant mission at the beginning of the 20th century, were all registered as Christians. In times of peace, many highlanders journeyed to the coast where education, health care, jobs and commerce were centralised.

The history of Seram is difficult to retrace. Although at the geographical centre of the Moluccas and the largest island of its archipelago, Seram holds a peripheral position in the official history of the region. The groups living inland can seldom trace their own history back more than 100 years. In pre-colonial times, West Seram was a sparsely populated area, located at the periphery of a large trading operation controlled by the north Moluccan sultanates. At least since the 14th century, the Ternatan, Bacanese and Tidorese sultanates had established alliances with coastal groups in the north and the south. West Seram, a halt along the trading routes, became a small producer of cloves (mainly on the peninsula of Huamual) and an exporter of sago. In the first half of the 17th century, Luhu, a vassal of Tidore on Huamual, became a prominent trading centre and a producer of cloves. ${ }^{6}$ No domain on Seram, however, could establish a realm of influence powerful enough to become a salient political centre in the Moluccas.

Between the 17th and the 19th century, the intervention of the Dutch East Indies Company (VOC) and the reorganisation implemented by the colonial administration progressively altered the situation on the coasts of Seram. Meanwhile, the more isolated western highlands retained most of their territorial and political autonomy until the end of the 19th century. Early reports sketch small independent domains with loose and changing alliances. Coastal and mountain communities were known to trade and intermarry but a general state of tension, enmity and warfare was reported between them. Indeed, the oral traditions of the Alune and Wemale who still occupy the western highlands recall numerous movements of population seeking land in the mountains as well as on the coast or migrating because of quarrels, illnesses or warfare. Such a state of affairs justified the intensive military 'pacification' campaigns and the administrative re-configuration of the highlands that took place in the early 20th century and continued during the post-colonial era.

As a result of this assimilation within the colonial and later national administrations, the region has been, during the past 100 years, subjected to ruthless and erratic changes. For the past four or five generations, its indigenous people have been implicated in warfare, guerilla activities and military occupation, and submitted to drastic 'modernisation' and relocation policies. They have also been confronted by intense deforestation of their environment and a massive influx of transmigrants. Since 1999, many more communities, old and new, have been displaced or dismembered. ${ }^{7}$ 


\section{'Wele Telu Batai}

'Wele Telu Batai takes its name from the three large river systems it encompasses. ${ }^{8}$ These three rivers flow from the Ulateina (ulate: 'mountain'; ina: 'mother'), a central mountainous watershed that bisects the highlands along an east west axis. The Eti River flows westward away from this central area to the sea, the Tala flows southward and the Sapalewa follows the divide for half of its course before flowing northward (see Map 1).

The traditional eastern boundaries of 'Wele Telu Batai correspond with the ancient partition of the island into Patasiwa, the 'Group of Nine', in West Seram, and Patalima, the 'Group of Five', to the east of it. This boundary was retained as the colonial administrative subdivision (onderafdeeling) for West Seram until the 20th century. ${ }^{9}$ The highlanders of West Seram were black Siwa (Patasiwa Hitam), initiated in the male brotherhood of the Kakehan to which most adult men belonged. ${ }^{10}$ The coastal settlers were white Siwa (Patasiwa Putih).

The Wemale and the Alune who occupy the highlands of 'Wele Telu refer to their river valleys and to the people who inhabit them as a single batai. Nowadays three administrative subdistricts, the Kecamatan of Seram Barat, Kairatu and Taniwel, correspond roughly with the traditional political divisions in these three batai, each regrouping the mountain domains and coastal settlements of a river valley. ${ }^{11}$ In the highlands, most modern desa correspond to a former traditional territorial unit or domain, the hena, some of which had ritual and/or political duties in the batai of their valleys. ${ }^{12}$

Until the beginning of the $20^{\text {th }}$ century, small-scale warfare and headhunting were frequent in the mountains and on the coast and everybody lived in mutual suspicion. Yet exchanges were vital and alliances, even temporary ones, were indispensable. ${ }^{13}$ Furthermore, the idea of a common origin linked to a central Mother Mountain and to a sacred cosmic banyan tree, the Nunusaku, was largely shared throughout West Seram, even among coastal newcomers. In this central Moluccan tradition, Seram is Nusa Ina the 'Mother Island', and Nunusaku, a giant and invisible banyan tree, stands on the Ulate Ina the 'Mother Mountain', of West Seram, which is the first abode of mankind and the symbolic centre of the region. ${ }^{14}$ Spreading its branches to the Heaven (Lanite) and its roots into the Hearth (Tapele), Nunusaku is also the source of the three rivers, which give the area its name. The cosmic banyan is said to extend its river trunks (batai) over the area, encompassing all the people of the region. 15

Nunusaku sama ite Nunusaku has distributed us

Sama ite 'Wele Telu Allotted us to the Three Rivers

Periodic assemblies of elders were called Nili. These councils facilitated relationships within this heterogeneous society. This widespread institution 
gathered the elders of small and large units, at the level of domains (nili hena: 'domain council'), river valleys (nili ela: 'large assemblies') and region (Nili 'Wele Telu Batai: the 'Assembly of the Three Large Rivers'). ${ }^{16}$ Although each small unit remained fiercely independent, these councils maintained some communication and coordination between the various coastal and highlands groups. Matters of regional interest and precedence were settled at the legislative and judicial level and later registered within the oral tradition. Thus the narrative of origin of Hena Ma'saman Uwei recalls various nili ela and bases several of its claims on decisions taken by these assemblies.

\section{The Nili Ela Organisation}

Large nili were held at the main coastal domains, alternating between the three rivers. Numerous animals were sacrificed and buildings constructed for guests since debates sometimes lasted several weeks. ${ }^{17}$ The felled trees on which the nili batai elders sat to deliberate were ritually felled in the forest. The logs were brought in procession by the participants and ceremonially placed on the ground. The representatives sat on them from base to tips according to the seniority of their office. The assembly started with the Tapea, ${ }^{18}$ a greeting chanted by the Herald. This greeting chant set out the order of precedence that applied for the specific meeting. Having called Tapele 'ai Lanite, 'the Earth and the Heaven', as witnesses, the herald welcomed the representatives of each river, chanting the full name of each domain, its position in the organisation and the title of its dignitary. The high-ranking dignitaries of the host coastal domain were greeted first, followed by the upstream coastal and highland domains of the same river. The same procedure (from coast to mountain) was repeated for each river batai.

Nili ela were primarily assemblies where conflicts between domains were brought for arbitration. Matters such as land disputes, murder or inter-domain feuds and corresponding compensation claims were discussed at length. The parties in conflict were assisted or pressured to reach an agreement, which was witnessed by the representatives of the whole region. The nili of one river was the point of convergence for highland and coastal groups to meet, interact and debate. A core group arbitrated these large conciliatory coastal meetings, which contributed to preserve some form of regional cohesion. Nili provided an arena in which wise and respected men could reassess the precedence of their domains and their own prestige.

At the beginning of the 20th century, the same model (probably modified over centuries) was replicated roughly in each of the three rivers' batai. The core group of the nili ela consisted of seven main positions per river batai. Each position was held by a specific domain and represented by its dignitary. The dignitaries changed (titles were usually hereditary) but the positions remained 
in the same domain, which had received that function in ancestral time. ${ }^{19} \mathrm{~A}$ domain could hold two positions, or two domains could hold one position jointly.

The seven positions were the following:

1 and 2. The Inama or Inama Latu ('Lord Mother Father') was the most senior position. ${ }^{20}$ In each of the rivers' batai, that position was held jointly by a large coastal settlement, as formal vassal of Ternate, and by a low hill settlement, supposedly representative of the highland domains: for example, Lisabata (coastal) and Nuniali (mountain) in the Sapalewa River Batai or Piru (coastal) and Eti (mountain) in the Eti Batai.

3. The duty of the Sarimetene ('Black Machete') was to present the cases to be arbitrated by the assembly. In each river, this position was held by the representative of the domain in charge of that duty.

4. The position of Anakota, the implementer of the decisions or sanctions of the assembly in each region, was filled by high dignitaries from one or two domains per river, who were called Anakota Mawena. ${ }^{21}$

5. The coastal domains designated in Alune as Inama Sariwei (Sari, Sali or Sael Uwei: 'the base/handle of the machete') held the positions of senior judges. Wemale used the metaphor of pole and flag to refer to the same position: Bandera Ehuwei ('the staff/pole of the flag'). ${ }^{22}$ These coastal dignitaries sat on the base of the felled trees used as benches by the council of arbitrators.

6. The position of Inama Saribubui (Sali or Sael Bubui: 'the tip, blade of the machete') was held by highland domains. ${ }^{23}$ Their representatives sat (in a junior position) on the tip end of the felled trunk of their river. The highland Inama Saribubui were the counterpart arbitrators of the coastal Inama Sariwei. The first one was the 'handle' and the later the 'blade' of the machete, which was the symbol of the arbitration.

7. The domains holding the position of Kapitan were in charge of summoning the members of their river batai to the assembly and their representatives were the envoys in charge of that duty. The role of interpreter and herald (alamanane) was also part of that duty. 24

Most but not all domains belonged to this alliance. ${ }^{25}$ When greeted and seated in front of the whole assembly, the domains were positioned in their Batai in an order of precedence from coast to mountain. 'The nili of one batai forms a tree,' explained a mountain elder. 'It gathers the riverine domains of one valley as the people and the land of one resting tree.' This tree lies with its 'base' (uwei), the 'core' of the tree, at the coastal centre, its branches (sanai) and tips (bubui) extend over the region and encompass the coastal and highland domains of the 
league. Figure 1, for example, depicts the tree-like pattern of alliance of Nili Sapalewa Batai, circa 1903.

\section{Figure 1: The tree of Nili Sapalewa Batai (circa 1903)}

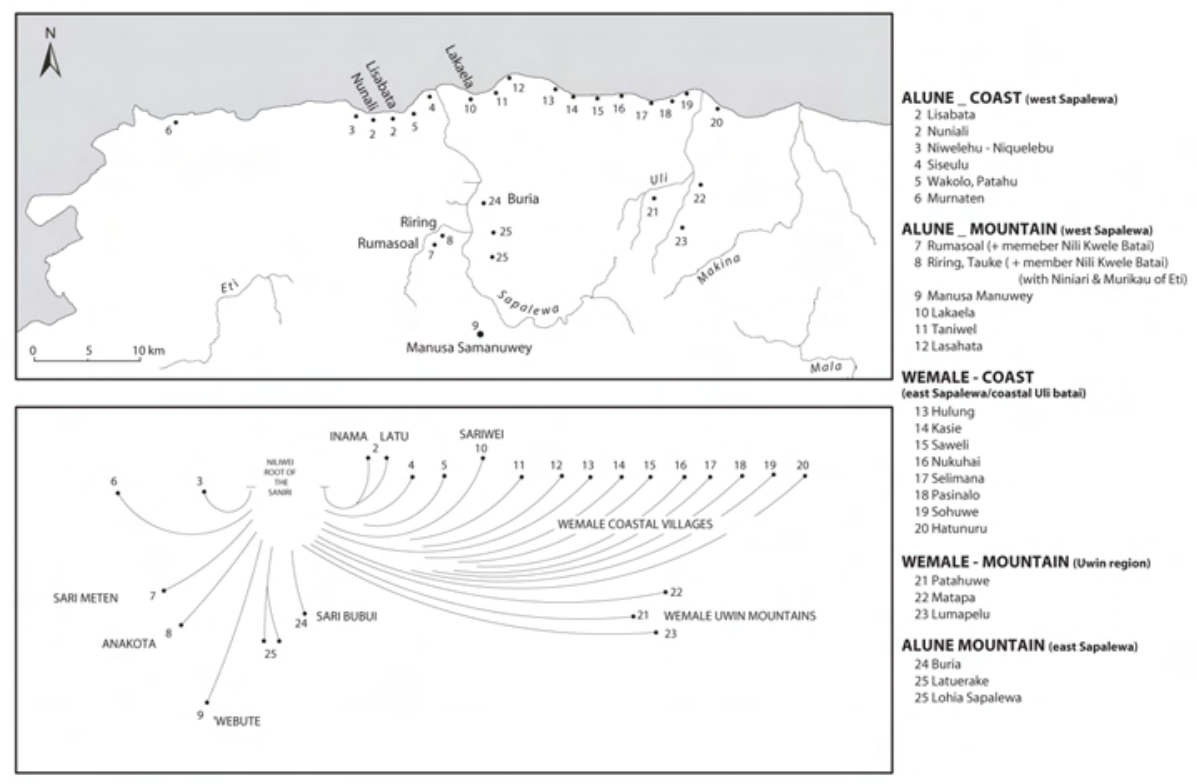

In each batai, the representative of a powerful coastal Muslim domain and his highland counterpart held the senior position (Inama Latu). Regarded as female and male (ina ama, 'mother father'), this dual position was given ultimate precedence as the Niliwei the 'core', 'base', 'source of continuity', of the nili. Other positions/duties were shared between coastal and highland domains. Seniority was accorded to larger and stronger domains, the seating position of these dignitaries reflecting this precedence. The most respected men of the region, and the resting trees on which they sat, together epitomised the batai as a political entity.

The league of the Three Rivers Batai held assemblies at a regional level. Yet, it had no strong centralised authority and was not bound by a single treaty. Domains were held together by their affiliation in a political organisation of elders and representatives, the nili, and in a men's brotherhood, the kakehan. ${ }^{26}$ The first provided a forum for arbitration (a court of justice); the second gathered them in a ritual brotherhood. 27

In each river batai, the domains were centred on a coastal 'core', their niliwei. It also situated them in an order of precedence that was oriented roughly from coast to mountain, from core/base uwei, to branches (sanai) and tip (bubui) and from elder/first (a mena) to younger/after (a muli). ${ }^{28}$ However, in the ritual 
matters of the kakehan, this precedence was reversed. Highland domains were Black Patasiwa and considered as the elders (a mena) and the coastal domains were the younger, White Patasiwa, who followed behind (a muli).

At the end of the 19th century, the necessity of relinquishing what was no longer a lucrative trade in spices gave rise to new colonial policies in the Central Moluccas. The first aim of the Dutch was to achieve full administrative control of the region, and the second to evaluate its economic potential for European free trading entrepreneurs. Accordingly, the exploration of the remote regions and their 'pacification' became a priority. ${ }^{29}$ The Colonial civil, military and religious administrators at the beginning of the 20th century attributed headhunting and the resistance against colonisation in West Seram to the kakehan and to the nili ela, to which almost all the coastal and mountain domains belonged. In 1914, after all attempts to transform these organisations into administrative instruments of the colonial bureaucracy had failed, the kakehan was banned, the saniri ela was officially abolished and their assemblies prohibited. ${ }^{30}$ The traditional leaders of political and religious organisations who were an obstacle to the colonial control of the region were converted or evicted; those who resisted were arrested or exiled and replaced by approved candidates. Smaller assemblies continued to be held secretly in the highlands until the 1950s but the modern subdistrict division, carved out of the 'Wele Telu, further diffused all batai unity.

\section{Nuru and Hena}

Before colonisation there was little restriction on mobility. The oral narratives give the impression that most communities experienced some division as they expanded, quarrelled or were defeated by a neighbour. Those who departed opened new regions, joined another group or took over some of its territory. Some domains had renowned war leaders (ama lesi, 'war father'). They were able, if required, to call on and obtain the support of other allied domains against a predatory neighbour, or to enrol them as a raiding partner. ${ }^{31}$ These authoritative and respected men were active members of the nili and the kakehan of their river, where followers (wife-takers) were coopted.

Among the Alune and the Wemale, origin groups are called nuru. Alune nuru perpetuate themselves by reference to a genitor line of derivation and Wemale nuru by reference to a genitrix one. Large nuru expand into new territories and set forth branches (sanai) over the whole region, establishing Houses (Luma) that can be found in more than one domain. ${ }^{32}$ Residency determines linguistic affiliation and mode of derivation of these Luma units. What all the members of a nuru have in common is a name. To this name is attached a narrative recalling the deeds of an ancestor and/or a place of origin. 
The people regarded as the descendants of the initial 'core' of a nuru constitute its nuruwei, its elder or 'initial trunk' (sumber, pohon). The claim to that prestigious position might be disputed between the 'branches' (sanai) of a nuru. Nuru order their 'branches' in different, sometimes combined orders of precedence. Thus a 'branch' might call itself a mena, the 'elder' ('firstborn', 'the one who walks ahead'), while another 'branch' might be a muli, in a junior position ('last born', 'the one who came after/follows'). Between them, a 'female branch' (bina) might have developed among various collateral 'branches'. As 'branches' grow and diversify, some keep their core name, recognising a common origin without necessarily keeping in contact with the initial 'core' (nuruwei). Other units take an additional name to distinguish their 'branch' and might forget their name of origin. 'Branches' might also sever the link with their initial nuruwei and initiate a new nuru (of which they become the nuruwei).

As nuru generate influential members and rich Houses, it is not so much a hierarchy that is established between them as a fluctuating competition. Renown and value are the objects of regular evaluation and readjustment. Thus claims for prestige and precedence apply between nuru and within them, between their 'branches' and Houses established in the various domains. However, there is little interaction between the various 'branches' of a nuru unless their Houses are in the same or a nearby domain. There is no nuru head, nor any authority that can be applied over a branch, a House or an individual by the nuru as a jural body. As some nuru become extinct, while the 'branches' of others transform themselves into a new core, it is difficult to make a precise count of the nuru and of their branches and Houses distributed across all Wemale and Alune domains and on other islands.

All nuru consist of 'Houses' or Luma. The first House to arrive in a domain is the Luma inai, the 'mother House', of its nuru in a domain. The Houses of the same nuru who arrived afterward, or decided to branch out from their Luma inai but remained in the same domain, are differentiated and called Luma sanai, 'branch Houses'.

The various Houses of a nuru, in one or several domains, are usually distinct and unrelated; however they do not intermarry. Sharing a common nuru name implies exogamy. It is by the intermediary of their Houses, which are exchanging units, that different nuru give and return brides to each other within or beyond a domain. Remote communities such as Hena Manusa Manuwe are essentially endogamous at domain level. Within the domain, the 'rich and famous' (hena upui: 'Grandfathers of the hena'), the elder and ruling lines, which have gained founding positions, exchange brides largely among themselves. But, through strategic marriages, proper behaviour and multiple descent, any House or any of its lines, including those perpetrated by women, may achieve status and 
wealth, enhance its renown and eventually fuse with, or replace, an older line or a declining House.

An Alune hena is a territorial, sociopolitical, economic and ritual unit standing in its own right. 33 The members of this community have joint assets and interests. They also share a sense of common identity and similar values, which derive from a strong awareness of the spiritual duties associated with their historical domain in the region. The entity called the hena comprehends the group, its settlements, its land, hills, rivers, forest and gardens, all named and narrated. It also includes all the dead and living beings dwelling within it.

Narratives depict how supra-human ancestors explored the region, marked territorial boundaries and assembled families (Luma), leading them through warfare and alliances to found a community. These founding ancestors established the position of their domain within the river batai and its institutions (the nili ela and kakehan). The following generations had to maintain these rights and gather enough followers to preserve a strong community and a large territory. As elders say: 'who adds people adds land.' 34 Nowadays, under the administration of the modern State, maintaining the number of their members remains a matter of survival for the highland communities.

One of these ancient domains is the Alune Hena Ma'saman Uwei, now called Desa Manusa Samanuwey (or Manusa Manuwe).

\section{Hena Ma'saman Uwei}

Ma'saman Uwei The place which is/the people who are at the origin/centre of the distribution/allotment

As one is told on first entering the hena of Ma'saman Uwei, this is 'the place from which everything in the world, land, people, tools, were distributed'. 35 This initial deed of its founding ancestor, Samai, 'the one who distributes', gave this domain a permanent and special status within the region as the ultimate source of wealth and fecundity to all the groups of the area. ${ }^{36}$ Because of this position, epitomised in its name and proven by its narrative of origin, this hena claims a central ritual position at the level of the entire 'Wele Telu Batai (and beyond). Similarly, the other domains make various claims, some of which are conflicting. Only strong groups can maintain such claims on their rights. Samai is renowned for having welcomed many people, building up a powerful domain that could defend and extend itself.

A topogeny is an ordered recitation of placenames, similar to a genealogy of people. ${ }^{37}$ The topogeny of Hena Ma'saman Uwei describes how the founding ancestors departed from their place of origin and followed a path of successive differentiation and bifurcations (between Patasiwa and Patalima, Black and 
White, Alune and Wemale, older brother at the coast and younger brother in the highlands). The ancestors finally delimited a territory and established the hena as a group of seven founding nuru (nuru itu). ${ }^{38}$ Nuruitu is the name given to the final site of the topogeny. There, the founding ancestors laid down seven stones, one for each of the seven unnamed nuru to establish the foundation of the hena. By doing so, they established the ritual centre that legitimises the social order of the hena and its territorial claims. The hill of Nuruitu overlooks the confluence of the Tau and the Sapalewa rivers. The Tau is the 'wele wei, the sacred 'water of origin', of the hena. At Nuruitu, through its origin river, the hena unites with the whole of the river batai. Downstream, it leads to the other groups of the Sapalewa batai, upstream to the Nunusaku. ${ }^{39}$

With time, the Houses of various nuru came and went. Some settled and expanded, others left, declined or became extinct. Ten years ago, Manusa Manuwe was made up of Houses from 15 different nuru, a number that fluctuates. However, while their identity might have changed, the number of founding nuru has remained fixed at seven. Seven is also the number of positions that order the ancient social organisation of the Hena and make it a complete body. These dignitaries hold the title of Hena Upui, 'Domain's Grandfathers' (or 'Ancestors').

These seven positions were: 1) Latu Ela Mena, 'Great Lord at the Front', the leader, ruler or head; 2) Upu Tapele, 'Grandfather of the Earth', the lord of the land; 3) Maeta'e, 'the One who Feeds the Stones', the ritual performer (the kakehan officiant); 4) Ama Lesi, 'Father of the War', the warlord; 5) Ama Nili, 'Father of the Nili', the leader of the village elders' assembly (and chief negotiator); 6) Alamane, the 'Spokesman', interpreter and herald, also called 'The Left Hand'; and 7) Ama Tita, 'Father Bridge', the liaison agent, also called 'The Right Hand'. ${ }^{0}$ The Great Lord, the Lord of the Land and the Ritual Performer were honoured by the title of Latu. These positions can be paired. Great Lord and Lord of the Land have complementary duties, so have the Warlord and the Nili Leader as well as the Left and Right Hands. The duty left out is the position of ritual performer, whose spiritual role extends over but also beyond it. These functions were superseded or altered under the colonial and new order administrations. However, most still carry a ritual or symbolic significance as modern position bearers perform comparable duties.

In Manusa Manuwe, most duties have remained consistently in the same nuru for several generations, thus the founding nuru and the founding duties of the Hena Upui mostly coincide. ${ }^{41}$ The Houses that do not hold one of the seven Hena Upui positions are Ana Mulini: the 'Younger Children' those who came after. ${ }^{42}$ However, the history of the Hhena shows that some 'Younger Children', have through time and appropriate alliances grown to be 'Domain's Grandfathers'. Since the narrative does not specify any nuru name as Hena Upui, in principle 
virtually any line can achieve the prestige and power to claim (or buy) such a position.

The seven duties implied in the name of the domain's ritual centre establish an ordered but flexible social organisation. It allows the indispensable insertion of new members in the community. The territorial groups of the nuru are their Houses. Groups recall coming from specific places, but after leaving this place of origin, each group became a landless family welcomed into another community. This insertion in a domain provides new groups with access to land and entry into a close-knit network of exchange and alliances in which to prosper. The hena is a territorial unit and only residence establishes someone's full membership in the community.

The nuru's Houses that claim the position of Hena Upui, the 'Domain's Grandfathers', are also those who claim the largest sections of the hena land. The order of precedence organised around these positions is still visible on the land and in the social organisation of the domain. The Ana Mulini have claims on smaller areas, however, they can receive communal land from the hena or land from another nuru, if their group increases. ${ }^{43}$

\section{Land Allocation in Hena Ma'saman Uwei}

The hena is a territorial unit. The elders insist on the inalienability of its land as a whole. Segments of it can be allocated for farming and other purposes but no section may be taken away, sold or even fenced. The community claims traditional rights over some 3,500 thousand hectares of land, a claim supported by narratives and the uninterrupted customary use of this territory for numerous generations.

The whole territory is called tape lale, the 'land within' ('inside', 'in the middle'). At its centre is the new settlement (desa). ${ }^{44}$ The land is distributed between the powerful Hena Upui and the junior Ana Mulini. The Hena Upui's claims to a substantial share of this 'land within', are embedded in the village history and in their own narratives. Also included in the 'land within' is the tape malenete, 'empty land' which no one occupies. The tape malenete is part of the historical territory claimed by the domain but not by individual Houses. 45 This 'empty land' also comprises the land of extinct Houses, which has not yet been redistributed. It is a common hunting, trapping and collecting ground but may also be used for communal projects. Outsiders, refugees or newcomers may receive access to the tape malenete to make gardens or plantations. 
Figure 2: The land and settlements of Hena Ma'saman Uwei

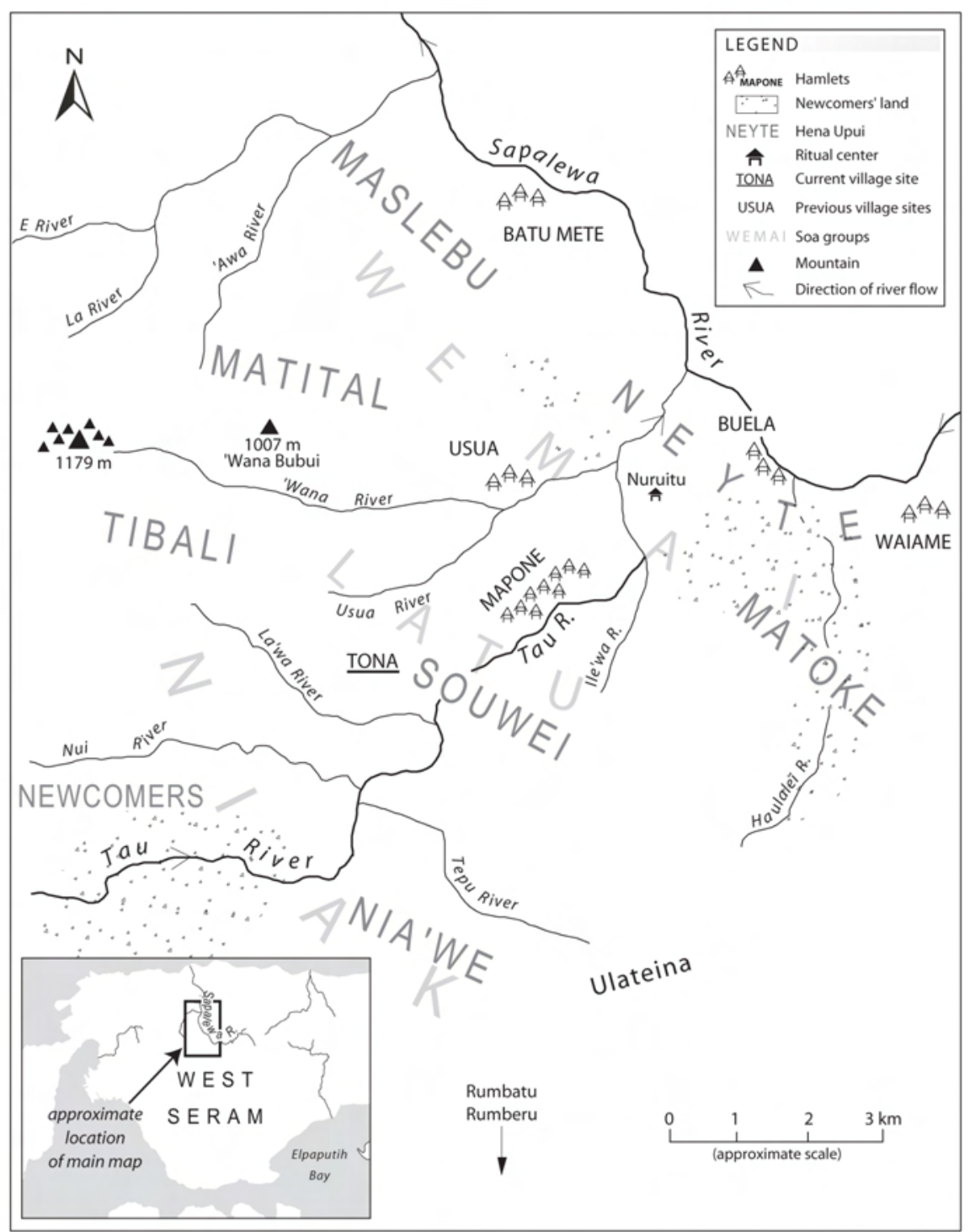


The Tau, the ancestral river, flows south-west to north-east across Hena Ma'saman Uwei before reaching the Sapalewa at Nuruitu, the ritual centre. At the centre of the hena, alongside the Tau and encompassing the new settlement and the ancient kakehan house, is the land of Souwei, the nuru of the Latu Upu Tapele, the Lord of the Land. In the north-east, besides Nuruitu, is the land of Matoke, the nuru of the Latu Maeta'e, the former Ritual Performer. Further north, on the path to the rival Wemale domain of Abio, is the land and post house of Neyte, the nuru of the former Ama Nili, renowned for negotiating a peace treaty with Abio. In the north-west, on the path to the powerful allied domain of Riring, is the land of Maslebu, the nuru of the Ama Lesi, the former Warlord, once marked by a large post house and the graves of prominent warriors. On the path to the north coast is the land of Matital, the nuru of the Ama Tita, 'The Right Hand'. Guarding the entry of the village to the south is the land of Nia'we, the nuru of the Alamane, 'The Left Hand'. The seventh nuru on the land is Tibali. ${ }^{46}$ The land of the newcomers, the Ana Mulini, is along the northern and southern paths to the hena's 'children' villages which developed from early garden houses closer to the coast. The position of 'Great Lord', village leader, alternates between different Upu Hena, hence there is no land for a ruler in the hena. ${ }^{47}$

One initiated elder described the land as a body. Other elders were unsure or denied this. In this model, the nuru carrying out the duty of Latu Upu Tapele, Lord of the Land, watches over the body of the land and the sacred river. The nuru of the Latu Maeta'e, Ritual Performer, is near the head of the ritual centre. The four members of the body are represented by the land occupied by the nuru of the Ama Lesi, the Warlord, the nuru of the Ama Nili, the nuru of the Alamane, or 'Left Hand', the Herald and the nuru of the Ama Tita, or 'Right Hand', the Liaison Officer. Of these four, the first two are more prominent, the latter more ancient in the area.

All the territory of the domain is under the corporate care of the hena. The tape malenete, 'empty land', is administrated collectively. Portions of the nuru land are under the custody of individual households. In Manusa Manuwe, most Houses have corporate rights over the land they use for gardens (mlinu), long-term plantations, orchards and groves (lusune, lusun, or lusu), hunting grounds and fishing pools. One says that a House 'sits' due on a portion of land and watches over its plantations ( $d a^{\prime}$ a lusune: 'to care for a plantation'). A portion of domain land that is claimed for its exclusive use by the House(s) of a nuru is called a lusun mena ('primary plantation'). The term mena marks precedence in space and/or time. The lusun mena is the common estate of all the associate members of a House. Unrelated branches of the same nuru have separate claims. Each lusun mena is administrated by a ntuane lusu, 'elder of the plantation', who must be consulted before new gardens are opened or plantations established on this common land. Households inherit rights to specific shares of the collective lusun mena of their House through the male line. 
The portions of lusun mena land claimed by each household (often shared with a brother or a nephew) are referred to as 'personal plantations' (lusu are 'ue: 'plantation my work'), but individuals own only the usufruct of their own and inherited plantations. ${ }^{48}$ The land on which someone's trees are planted remains in the custody of his/her House. Ultimately, however, all land belongs indivisibly to the community of the hena and no one possesses exclusive title or has the right to sell any segment of land. ${ }^{49}$

A person's plantations (not the land itself) are his/her lusun dati. Every lusune has a name and belongs to a dati, unit. Typically, a dati (the term is widespread in Central Moluccas) is an administrative unit of people (relatives or allies) in relation to service, tax and commitment on the one hand, and the use of the land on the other. In the highlands, it is usually the members of one or several Houses of the same nuru who form a dati under the arbitration of an elder, the ntuane dati. A dati might include one or several lusun mena. ${ }^{50}$ Lusun dati are planted by successive generations for themselves and their descendants. Theoretically, outsiders cannot 'eat' (ane) from these plantations, but newcomers or followers may be integrated. Some Houses have little lusune land, and if their households increase, they might quarrel over the use of the usufruct of the trees of their common lusune. Elders say that if a man is wise, he will plant as many separate lusu plantations as he has sons so that each of them may add to his own lusu and pay for schooling or buy what he needs. Thus an individual has access to the lusun mena of his House and may nominally own some trees privately in lusun dati. Relatives can collect some products from this land but there are restrictions. $^{51}$

Long established Houses (hena upui) that have access to a large portion of land might allot a section of it to a landless family of newcomers (ana mulini) securing them as followers. Alternatively, a ntuane dati might allow someone of the village or a newcomer to make a garden (mlinu: short term plantation and forest farming) on the land of his group. It might be advantageous for all to do so as no outsider can settle on a parcel of land that is already worked by someone. In such cases, the dati group always maintains precedence on that land and the ntuane dati dictates the terms of its use. Once given, this right of use is hereditary and need not be requested again. The dati group, however, retains the right to recover the land at any time. ${ }^{52}$ Reclaiming a parcel of land can produce tension or hostility so groups are cautious in taking the decision to allow an outsider to work on their dati land.

Land is transmitted through males, but an unmarried daughter who resides in her father's house with her children might be given custody of his land until her son is of an age to care for it by himself. ${ }^{53}$ A woman who marries still has limited access to the lusune of her House of origin but she cannot plant long-term plantations on it. Most widows regard themselves as dispossessed and landless; 
however, they are usually cared for by one of their children or by relatives who allow them to make a garden and take a share in the usufruct of their plantations. ${ }^{54}$

There is no market in Manusa Manuwe and forest gardens are sometimes at several hours' walk. For generations, people have planted edible leaves and fruit trees along the paths to sago groves, gardens, fishing and hunting grounds so that no one will go hungry on the way to and from the forest. As they go hunting or sago-beating together, brothers-in-law also plant trees on each other's land for their children as a sign of conviviality. Nowadays, the dati group usually discusses which parcel each member will farm that year, but mlinu, annual gardens (mountain rice interspersed with corn, cassava and vegetable), are planted and tended individually. ${ }^{55}$ A garden is planted twice or a maximum of three times after which it is left fallow for about 25 years before the caretaker or his/her descendant returns to clear the land again. Meanwhile, fruit and other useful trees mark boundaries and signal occupancy.

\section{Conclusion}

This paper has examined the organisation of 'Wele Telu Batai, the League of the Three Large Rivers, and its batai. It has also examined one constituent riverine valley subdivision of this batai, the Hena Ma'saman Uwei and the institutions associated with territoriality and land usage within it.

The nili ela and nili batai supported a wide network of alliances and economic exchanges. The institution acted as a political arena as well as a court of arbitration. Its members acknowledged the Nunusaku as the central feature of the common cosmic order organising their relationships. Men were bound by the brotherhood of their initiation cult, its rules, ritual practices and celebrations. Gathering the domains of the Three Rivers and their most noted dignitaries, the nili assemblies preserved a form of cohesion between the domains of the Three Rivers, the strength of this coalition offsetting the region's general instability.

Once all attempts to use or transform these assemblies into administrative instruments of the colonial bureaucracy had failed, the nili ela and nili batai were officially abolished, their meetings prohibited, non-compliant dignitaries eliminated and harsh punitive expeditions launched against any form of resistance. At the dawn of the 21 st century, cohesive modern institutions have yet to replace the Nili Ela 'Wele Telu or the riverine nili batai. 56

In contrast with the nili ela organisation, the hena successfully incorporated various formative influences and successive transformations imposed by the centralised administrations in the past two centuries. The capacity to adapt according to context, while still keeping the core principles of its initial structure, has served and preserved a traditional form of social order within the hena. The living body of narratives that constitute and continuously update the origin 
structures of the domain supports this social order. This flexible and semi-openestructure allows the insertion of newcomers (and new ideas) that are essential to ensure the continuation of the community.

Each domain (hena) in its river valley and each House in the hena is a custodian of a share of common land, its history and its natural and spiritual environment. The social identity of these units is embedded in the land. It translates continually into action, ritual and political duties, ordering the interactions of constituent groups and their precedence within the domain, its river valley and within the League of the Three Rivers.

\section{References}

Blust, R. 1980. 'Early Austronesian Social Organisation: The Evidence of Language.' Current Anthropology 21 (2). pp. 221-47.

Boulan-Smit, C. 1998. 'We of the Banyan Tree: Traditions of Origin of the Alune of West Seram.' Unpublished PhD thesis, Department of Anthropology, RSPAS, The Australian National University, Canberra.

Boulan-Smit, C. 2001. 'Founding Communities: Departure, Arrivals, Returns and Resettlements in West Seram.' In J. Sikala (ed.), Departures: How Societies Distribute their People, Helsinki: The Finnish Anthropological Society TAFAS 46. pp. 7-21.

Fox, J.J. 1989. 'Categories and Complement: Binary Ideologies and the Organisation of Dualist in Eastern Indonesia.' In D. Maybury-Lewis and Uri Almagor (eds), The Attraction of Opposites: Thoughts and Society in a Dualistic Mode, Ann Arbor: University of Michigan. Pp. 33-56.

Fox, J.J. 1994. 'Reflection on "Hierarchy" and "Precedence".' In M. Jolly and M. Mosko (eds), Transformations of Hierarchy: Structure, History and Horizon in the Austronesian World, Special issue of History and Anthropology 7 (1-4). pp. 87-108.

Fox, J.J. 1995a. 'Origin Structures and Systems of Precedence in the Comparative Study of Austronesian Societies.' In P.J.K. Li, Cheng-hwa Tsang, Yingkuei Huang, Dah-an Ho and Chiu-yu Tseng (eds), Austronesian Studies Relating to Taiwan, Taipei: Symposium Series of the Institute of History and Philology, Academia Sinica, No. 3. pp. 27-57.

Fox, J.J. 1995b. 'Austronesian Societies and their Transformations.' In P. Bellwood, J.J. Fox and D. Tryon (eds), The Austronesians: Historical and Comparative Perspectives, Canberra: Department of Anthropology, Comparative Austronesian Studies Project, RSPAS, The Australian National University. pp. 214-28.

Fox, J. J. 1997. 'Genealogy and Topogeny: Toward an Ethnography of Rotinese Ritual Place Names.' In J.J. Fox (ed.), The Poetic Power of Place: Compar- 
ative perspectives on Austronesian ideas of locality, Canberra: Department of Anthropology, Comparative Austronesian Studies Project, RSPAS, The Australian National University. pp. 91-102.

Jensen, A.D.E. 1977. 'Indigenous Classification Systems in the Ambonese Moluccas.' In P.E. de Josselin de Jong (ed.), Structural Anthropology in the Netherlands, The Hague: Martinus Nijhoff (KITLV Traduction Series, 17). pp.101-15.

Jensen, A.D.E. and H. Niggemeyer. 1939. Hainuwele: Volkserzählungen von der Molukken-Insel Ceram. Frankfurt am Main: Klostermann.

Knaap, G.J. n.d. 'The Saniri Tiga Air (Seram): An Account of its "Discovery" and Interpretation between about 1675 and 1950.' In B.K.I. Deel, 149 (2). pp. 250-73.

McWilliam, Andrew. 1989. 'Narrating the Gate and the Path: Place and Precedence in Southwest Timor.' Unpublished PhD thesis, The Australian National University, Canberra.

Sachse, F.J.P. 1907. Het eiland Seran en Zijne Bewoners. Leiden: Brill.

Sachse, F.J.P. 1922. 'Seran: Mededeelingen van her Bureau voor Bestuurszaken der Buitengewesten.' Encyclopaedisch Bureau, No. 24.

Tauern, O.D. 1918. Patasiwa und Patalima. Vom Molukkeneiland Seram und seinen Bewohners. Leipzig: Voitgelander.

Traube, E.G. 1980. Cosmology and Social Life: Ritual Exchanges amongst the Mambai of East Timor. Chicago: University of Chicago Press.

van Wouden, F.A.E. 1968 [1935]. Type of Social Structure in Eastern Indonesia. (English translation by R. Needham). KITLV Translation Series 11. The Hague: Nijhoff.

\section{ENDNOTES}

\footnotetext{
1 Jensen (1938: No. 73,126; Summarised translation).

${ }^{2}$ League: (Lat. ligare: to bind) an association of nations or other political entities for a common purpose; an association of people or groups united by a common interest or goals; an informal alliance (Webster's Ninth New Collegiate Dictionary 1991).

3 In 1990, elders remembered that assemblies were held secretly in the forest if important inter-domain matters such as war or a land dispute had to be arbitrated.

4 Some went far inland. Thus, Tauern (1918: 29-30) attributes a Halmaherese origin to the Alune, a highland group of West Seram who are also credited with introducing the loom and the knowledge of woven fibres.

5 The paper is based on several fieldwork trips carried out in the area in 1983, 1985 and 1991-92.

6 Luhu, a large coastal settlement, was referred to as a kota, 'town'.

7 The inter-communal violence that rocked the Moluccas between 1999 and 2003 tore apart dozens of communities, killing an estimated 15,000 people and displacing more than half a million as refugees. In the process, communal and individual lands have often been appropriated and redistributed. People are returning slowly to rebuild their shattered communities, but as witnessed in the history of the area, unresolved land issues could constitute a significant obstacle to securing a lasting peace.
} 
8 The traditional name of West Seram is 'Wele Telu Batai, the Three Large Rivers Trunks: 'Wae'we, kwae, kwe means river; le, ela: large; telu: three; and batai is a classifier for large oblong objects such as a log or the trunk of a felled tree. Batai is also used to refer to a river valley or a mountain range and to the people who inhabit it. "Wele Telu Batai is adjacent to but excludes the westernmost peninsula of Huamual.

9 It is delimited by the Makina River in the north and the Mala in the south.

10 The kakehan, about which we know very little although much has been written, was described as a masculine secret society acting as a large regional association of male initiation groups. The brotherhood was characterised by initiation practices, secret paraphernalia, ritual seclusion of boys in men's houses, warfare and ritual murder (headhunting).

11 Their three coastal ibu kota (administrative centres) are Piru, a few kilometres north of the mouth of the Eti River, Kairatu, south-west of the Tala, and Taniwel, east of the Sapalewa.

12 Domains can be referred to as kota, inama or anakota in relation to their position within their batai.

13 The highlanders depended on the coast to obtain goods such as salt, weapons or heirloom objects; the coastal settlers traded these goods for forest products and services.

14 The name Seram ('frightening') evokes a dark, mysterious passive and powerful source of life.

15 According to M. Sijauta S.J.M., a prominent Ambonese Alune elder in 1983, Ulate Ina, is recalled as the 'Mother Mountain, mother of all Uli' (territorial groups).

16 In Ambonese, Saniri Besar or Saniri Hutu. In Alune, used as a verb, the word nili means 'to mix' or 'to arouse'. Mixing people and ideas and stirring them into actions was a purpose of the nili.

17 The early colonial civil servants and administrators regarded these nili ela (or nili batai) as a waste of resources and as potentially dangerous political gatherings.

18 Tapele: the land, the Earth, as opposed to Lanite: the sky, the Heavens.

19 People believed in a form of metempsychosis along family lines. Thus one might say that the function was also regarded as staying with the 'same' persona.

20 Following Blust's reconstruction (1980: 217), the Proto-Malayo-Polynesian *datu offers four possible components: 1) political leader, chief; 2) priest; 3) aristocrat, noble; and 4) ancestor, grandfather, elder. According to Belwood (1996: 19), the datu is probably a lineage- (or clan-)like official. Traditionally in Seram, the title of Latu, Lord, suggests a leading position rather than a specific duty. A Lord of the Land, a ruler, a high priest or a warrior may all be honoured by the title of Latu.

21 Authors usually translate Mauwen or Mawene Anakota ('captain of a boat') as 'High Priest' because the Mauwena were also leading dignitaries of the kakehan. Indeed, the brotherhood was also ensuring that traditional law was implemented among its members.

22 In Bahasa Indonesia: Pohon Bandera.

23 Wemale: Bandera Erui: 'Tip of the Flag'; Bahasa Indonesia: Udjung Bandera. 'The imagery [of flag and pole, base and tip] evokes a paradigm of objects that stand fixed in place and reach upward toward the sky. Like such axis mundi as the cosmic mountain, the world tree, and the origin house, the union of the pole and flag expresses a hierarchical distinction between one who plants, grips and steadies the foundations of a structure and one who keeps it upright and erect' (E.G. Traube 1980: 57).

24 The title of kapitan evokes a war leader (Kapitan Perang). It was first given by the crews of Portuguese ships who visited the region to the spokesmen with whom they had contact and who seemed to lead their groups since they came forward. These kapitan (the title was incorporated in various local languages) were the dignitaries in charge of the relationships of their domain with the outside. By extension, the envoys of the nili received the title of kapitan. The ancient Alune highland name for the same function was alamanane. Alamanana means 'to intone', alamanane, a 'ritual chant', and the alamanane or $m a^{\prime} a$ alamanane was 'the one whose office is to chant', the other duty of the kapitan or alamanane.

25 Thus, the Wemale domains of Abio Batai, Walokone and Waraloin in the upper Uli and Sapalewa Rivers area do not seem to be mentioned anywhere in relation to the Nili 'Wele Telu Batai. Other coalitions were also formed within or outside the nili. For example, the domains of Rumasoal and Riring respectively, Sarimetene and Anakota of the Sapalewa River batai, were also part of another independent alliance called Nili Kwele Batai (the 'Assembly of the Big River') with three other highland domains of the upper Eti River (Niniari, Murikau and Lumoli). This coalition had its own representation in the regional assembly (Nili 'Wele Telu Batai). As an indigenous highland association, it counterbalanced the influence of the rich and powerful Muslim coastal domains of Kaibobo (Eti) and Lisabata (Sapalewa), both former vassals of the Ternatan governor of Luhu (Huamual). The Nili Kwele Batai later played an important role in the resistance against the Dutch colonisation of the highlands. 
26 Authoritative members of the kakehan were prominent elders in the nili. Throughout the region, groups and their allies received each other in large men's houses, built semi-buried deep in the forest, to perform ancestral rituals, duties, and to celebrate and debate local politics.

27 In 1914-16, the league had attained enough cohesion to propagate a succession of uprisings, from domain to domain along each river valley, in a last attempt to resist colonisation.

28 Mena means: 'first', 'primary', 'earlier', 'in the front' or 'before', as opposed to muli: 'after' or 'behind', 'in the back', 'last'. The distinction between 'core' and 'tips' or 'branches' and between those who are 'in the front' and those who are 'in the back' is used to construct the recursive asymmetric relational categories that mark precedence (see Fox 1994, 1995).

29 Pacificacie: the ruthless military repression of any form of rebellion (including peaceful flight) against the imposition of colonial rule.

30 Kakehan and nili ela were undoubtedly related, if only because prominent elders and political leaders assembled in both councils. However, the kakehan was of the order of adat agama, a 'religious tradition', now disappeared, while what remains of the nili (at village scale) is still concerned with adat pemerintah, a 'traditional administration', that was regarded by the colonial and new order Indonesian administrations as cumbersome remnants of a past to be disposed of.

31 The renown of an important individual or his personal wealth in ceremonial objects enhanced the prestige of his domain, re-enforcing its position within the batai.

32 House and Luma with a capital ' $\mathrm{H}$ ' and ' $\mathrm{L}$ ' are used to distinguish these social units from the 'house' (luma), the building of the same name.

33 The domains of 'Wele Telu Batai were called hena inama kota or anakota in relation to their position in the nili of their river.

34 In Bahasa Indonesia: tamba jiwa tamba tanah.

${ }^{35} M a^{\prime} a$ is an agentive, locative or genitive noun forming a prefix, which is affixed to the verbal root. Thus it conveys the triple idea of 'the people who', 'the place where', and 'the origin of'. Sama means 'to share', 'divide', 'split up', or 'allot' (Bahasa Indonesia: bagi); ne is the nominative marker. The word uey, wei or uwei can be translated as 'origin', 'beginning', 'centre', 'source of continuity' and also 'junction point' (Bahasa Indonesia: pusat: 'centre', 'navel').

36 Samai is also referred to as Latu Pati Ama Samane: 'The Lord Dignitary Father (who) Distributes'.

37 'An ordered succession of place names' that establish precedence in relation to a particular starting point - a point of origin. Generally these topogenies assume the form of a journey: that of an ancestor, an origin group or an object' (J.J. Fox, 1997: 91).

38 In the ilmu 999, a numerical system widespread in the region and beyond, the number nine is used to represent any totality, and seven is one of the combination of numbers used to represent social units, clans, rulers, bodies, etc. In that system elements are grouped to form units. Each complete unit is counted as one element of its sub-units for it represents the totality of them (a body represented by its head). There is only one totality per unit. As a result, when units merge the final combination shows only one totality.

39 The realm of the dead is upside down and the opposite of the world of the living. While the fecundating river waters flow downstream, the ancestral substance returns upstream via the three rivers to the Nunusaku. Those of Manusa Manuwe follow the Sapalewa.

40 Tita: 'to cross over', 'to visit' and, by extension, 'to trade'.

41 In the modern desa too, members of nuru still regarded as Hena Upui often hold administrative functions. This is not so much the remnant of 'feudal practices' but merely the fact that some representatives of these Houses have the experience, the authority and the network of allies that allow them to perform their tasks. These positions are challenged by newcomers, particularly the position of 'Great Lord' (now Kepala Desa), one of the most accessible.

42 Because the hena regards itself as the origin of all the groups in the area, all newcomers finds themselves in the position of one who 'returns' (leu) to Manusa Manuwe.

43 Who is someone else's land giver and who was a mena (elder) on a piece of land is forgotten only if the group who watched over it becomes extinct.

44 The ancient hamlets were amalgamated in three soa in the 1920s and the whole population regrouped in one village in 1977.

45 In Bahasa Indonesia, it is referred to as tanah sejarah.

46 The topogeny of the Hena Ma'saman Uwei recalls the bifurcations and differentiations of the first ancestors as they follow the path that leads them down and away from the undifferentiated place of 
origin (the Nunusaku). While Samai, the founding ancestor of the hena, and his followers established the ritual centre of Nuruitu, his elder brother Latuelamena (the 'Big Lord in the Front') left with the regalia that testified to the history of origin. He settled at the coast with his followers and found the powerful Alune low hills domain of Eti along the river of the same name. Eti was the Inama, the 'Mother-father', of the Eti River's nili and was allied with Ternate through its relationship with Piru, the political centre of the south west coast. At that time, says the narrative, Latuelamena took the nuru name of Turukai. The small 'shots' of his nuru who remained with Samai in Hena Ma'saman Uwe $i$ were nicknamed anasosi, 'ignorant children'. Their descendants are the Houses of nuru Tibali. They still insist on their 'ignorance' but their nuru controls a substantial portion of the hena land near the path to the south coast, where newcomers are welcomed to settle (see Fig. 2).

47 Between 1916 and 1990, the position of Great lord (variously called regent, Radja, Pesawat and Kepala Desa) was held successively by elders who belonged to the nuru of the Upu Tapele, the Latu Maeta'e, a follower of the Ama Lesi, and the nuru of the Ama Nili.

48 Even the rights on this usufruct are not exclusive in as much as everyone is expected to share and nothing is fenced (except by traps and prohibition signs).

49 During the New Order, this system became vulnerable to manipulation and abuse. In Manusa Manuwe, a lumber company was granted the rights to fell large sections of forest on the land of several Houses by 'the community', i.e. the civil servants put in place by a corrupted regional government. These Houses were never adequately compensated.

50 At the beginning of the $20^{\text {t }}$ th century, the highlanders who lived in hamlets on their respective House land had to register themselves with the Dutch Colonial Administration and regroup in larger settlements along a path to the coast. In Manusa Manuwe, the dati system was probably introduced during this period and integrated by the people into the local lusu system.

51 Closer relatives have more rights than others, but all should apply restraint.

52 The Ntuane dati might signal to the user family that the group is claiming the parcel back by planting long-term plantations on it.

53 In Manusa Manuwe, the rights of one line can be transferred through unmarried women for several generations until a suitable male heir is born.

54 A man who cares for his wife will leave instructions for her care to his children.

55 In the past relatives, allies and friends harvested and celebrated jointly with the ancestors. The New Order Government and the Church discouraged the practice of this 'wasteful' and 'backward' thanksgiving ritual.

56 It remains to be seen if the nili hena ('village council') will be revived in a new form within the LMD (Lembaga Masyarakat Desa: Fellow Villagers' Association). 